\title{
DISCORRENDO SOBRE OS PERİODOS PRÉ E PÓS FLORENCE NIGHTINGALE: A ENFERMAGEM E SUA HISTORICIDADE
}

Objetivo: Refletir sobre a teoria ambientalista de Florence Nightingale, contextualizando a Enfermagem moderna frente suas origens e o desenvolvimento de sua prática. Método: Estudo reflexivo, de perspectiva histórica e que utiliza a pesquisa documental como método de investigação. Tomou por base especialmente artigos de periódicos científicos e livros clássicos sobre a história da enfermagem e suas concepções, sem limite de data de publicação. Resultados: $O$ texto percorre desde as origens do cuidado ligadas à religiosidade, a perda da hegemonia da igreja quando as religiosas foram expulsas dos hospitais até a figura de Florence Nightingale como precursora da enfermagem moderna, destacando a Teoria Ambientalista, relacionando-a a prática de comportamentos no enfrentamento da atual pandemia. Conclusões: Discorrer sobre a história da enfermagem e sua trajetória profissional a partir de seus marcos clássicos é necessário, inclusive para a compreensão de dogmas e paradigmas que ainda são inerentes à sua prática.

Descritores: História da Enfermagem; Teorias de Enfermagem; Enfermagem.

\section{TALKING ABOUT BEFORE AND AFTER THE FLORENCE NIGHTINGALE PERIODS: THE NURSING AND ITS HISTORICITY}

Objective: To reflect about Florence Nightingale's environmental theory, contextualizing the modern Nursing in view of its origins and the development of its practice. Method: A reflective study, from a historical perspective, using documentary research as an investigation method. It was based mainly on scientific articles and classic books on the history of nursing and its conceptions, without limit on the date of publication. Results: The text goes since the origins of care linked to religiosity, the lost of hegemony of the church when the nuns were expelled from hospitals until the figure Tof Florence Nightingale as a precursor of modern nursing, highlighting the Environmental Theory, relating it to the practice of behaviors in facing the current pandemic. Conclusions: To talk about the history of nursing and its professional trajectory since its classic demarcation is necessary, including the understanding of dogmas and paradigms that are still inherent to its practice.

Descriptors: History of Nursing; Nursing Theories; Nursing.

\section{DISCURSANDO SOBRE LOS PERÍODOS PRE Y POST FLORENCE NIGHTINGALE: LA ENFERMERÍA Y SU HISTORICIDAD}

Objetivo: Reflexionar sobre la teoría ambiental de Florence Nightingale, contextualizando la enfermería moderna en vista de sus orígenes y el desarrollo de su práctica. Método: Estudio reflexivo, desde una perspectiva histórica, que utiliza la investigación documental como método de investigación. Se basó principalmente en artículos de revistas científicas y libros clásicos sobre la historia de la enfermería y sus concepciones, sin límite en la fecha de publicación. Resultados: El texto va desde los orígenes de la atención vinculada a la religiosidad, la pérdida de la hegemonía de la iglesia cuando las monjas fueron expulsadas de los hospitales hasta la figura de Florence Nightingale como precursora de la enfermería moderna, destacando la teoría ambiental, relacionándola con la práctica de comportamientos frente a la pandemia actual. Conclusiones: Es necesario hablar sobre la historia de la enfermería y su trayectoria profesional desde sus hitos clásicos, incluso para comprender los dogmas y paradigmas que aún son inherentes a su práctica.

Descriptores: Historia de la Enfermería; Teorías de enfermería; Enfermería.

${ }^{1}$ Hospital Regional de São José Dr. Homero de Miranda Gomes.

${ }^{2}$ Professora da Escola de Enfermagem da Universidade Federal de Minas Gerais.

Autor Correspondente: Miguir Terezinha Vieccelli Donoso E-mail: miguirdonoso@uol.com.br Recebido 28/4/2020 - Aceito: 16/5/2020 


\section{INTRODUÇÃO}

A identidade das profissões e sua historicidade perpassam pela história da humanidade. Os estudos históricos interessam à Enfermagem, pois o desvelamento da realidade mediante o estudo da história favorece à contextualização e ao entendimento da profissão e de sua identidade. A história de uma profissão pode ser contada por quem a vivencia na prática, a analisa ou a imagina ${ }^{(1)}$.

A Enfermagem como profissão, nunca esteve tão comentada na mídia como nessa segunda década do século XXI. Nesse período de pandemia, enfermeiros, técnicos e auxiliares de enfermagem caminham na linha de frente, como profissionais instituídos de saberes científicos, atores sociais de uma profissão sistematizada e pautada nos seus próprios alicerces e regulação profissional. De trabalhadores desprovidos de qualquer conhecimento próprio da profissão, resignados e cumpridores de ordens, no passado, a profissionais discutindo sistematização da assistência, humanização do cuidado, diagnósticos de enfermagem, interdisciplinaridade e teorias de enfermagem, na atualidade. Estamos evoluindo, considerando que para uma evolução concreta científica da enfermagem, os profissionais são desafiados à superação de problemáticas a muito já reveladas ${ }^{(2)}$

Contextualizando a Enfermagem como possuidora de um corpo de conhecimentos específicos, torna-se imprescindivel estudar seus referenciais e a história de suas precursoras. Este texto tem como objetivo refletir sobre a teoria ambientalista de Florence Nightingale como paralela ao atual momento histórico social e mundial de saúde. Trata-se de texto reflexivo, que utiliza a perspectiva histórica como referencial teórico.

\section{MÉTODO}

Estudo que utiliza a pesquisa documental como método de investigação. A elaboração deste estudo tomou por base especialmente artigos de periódicos científicos e livros clássicos sobre a história da Enfermagem e suas concepções, sem limite de data de publicação, possibilitando reflexões e contextualização da prática em seus diversos cenários de atuação.

\section{Pré-Florence: Enfermagem pré-profissional}

Desde os tempos antes de Cristo, a convicção de que a doença era um castigo de Deus levou os povos primitivos a recorrer aos sacerdotes ou feiticeiros, que acumulavam as funções de médico, farmacêutico e enfermeiro. Os tratamentos tinham por objetivo aplacar as divindades por meio de sacrifícios expiatórios e afastar os maus espíritos. Ao se adquirir os conhecimentos práticos sobre plantas medicinais, o preparo e a administração desses remédios foram delegados a assistentes, que tinham as funções de farmacêutico e enfermeiro(3). A palavra Hospital tem origem no latim como adjetivo derivado de "hospes" que significa estrangeiro, viajante, que dá agasalho e que hospeda. As casas reservadas aos tratamentos temporários dos doentes eram chamadas de hospitais ${ }^{(4)}$.

Ruínas descobertas na região do Danúbio mostram que por volta do século IV a.C., na Europa Ocidental, os hospitais militares romanos eram organizações institucionalizadas. Um dos mais importantes hospitais da história foi o Hotel Dieu de Lyon, criado em 542 por Childebert, no concílio de Orleans, sendo este destinado a receber pobres, órfãos e peregrinos. Outros hospitais na época foram criados em Paris, com o objetivo de receber escolares e peregrinos ${ }^{(4)}$.

A senhora Luisa de Marillac e o padre Vicente de Paulo levaram a confraria da alta nobreza de Paris aos leitos dos doentes do Hôtel - Dieu. Este hospital estava sob a dependência dos cônegos da Catedral e o serviço interno era dirigido pelas irmãs agostinianas. Embora trabalhassem neste local cerca de 150 religiosas, dentre elas 50 noviças, esta casa de cuidados era um lugar insalubre, sem leitos limpos, sem uma disciplina minuciosa e com alimentação insuficiente. Porém, o número de doentes era muito elevado, entre 1200 e 2000. As camas eram quase encostadas umas as outras e comuns a vários doentes, chegando a conter, cada uma, seis doentes, três deitados em um sentido e três no outro. A confraria da caridade contava com mais de duzentas senhoras. O religioso Vicente de Paulo foi nomeado diretor de todo serviço espiritual do Hospital e a mesa diretora foi formada e coordenada pelas senhoras da Confraria da Caridade ${ }^{(5)}$.

O cuidado aos doentes era atrelado ao espírito de doação e a abnegação, que aparecem como prioridades nas exigências àquelas que iriam cuidar do corpo do outro, naquelas que seriam as "enfermeiras". O plano de conduta das irmãs de caridade prescrevia sempre o serviço espiritual aliado aos cuidados corporais, devendo ambos ser realizados com humildade. Todas as candidatas deveriam aprender as três virtudes formadoras da alma das irmãs de caridade: a humildade, a simplicidade e a caridade ${ }^{(6)}$

A imagem religiosa da enfermeira se desenvolveu na Era Cristã e Idade Média, com organizações voltadas para a caridade e o cuidado de doentes, pobres, idosos e órfãos. À medida que a Enfermagem desenvolvia uma imagem associada à religião, uma disciplina cada vez mais rígida era imposta, sendo também determinada a obediência absoluta às ordens dos médicos e dos sacerdotes ${ }^{(7)}$. 
O Renascimento (séc. XIV a XVI) provocou uma revolta contra a supremacia da Igreja Católica, quando foram dissolvidas diversas ordens religiosas e o trabalho das mulheres nessas ordens foi extinto, iniciando assim o periodo obscuro da Enfermagem ${ }^{(5)}$. Com a perda da hegemonia da igreja, as religiosas foram expulsas dos hospitais, sendo substituidas por mulheres de "baixa qualificação moral" conforme os valores da época. Estas assumiram o cuidado aos enfermos em troca de baixos salários, sendo esse período significativo para a história da Enfermagem ${ }^{(8)}$.

A Reforma Protestante pregava a fé sem a penitência e o Renascimento incentivava o pensamento lógico leigo e a valorização da liberdade de ações. Foram essas duas correntes que afastaram as religiosas dos hospitais. Os hospitais passaram a ser um insalubre depósito de doentes, ambiente de miséria e degradação humana, onde as cuidadoras desenvolviam suas atividades, essencialmente domésticas sob exploração, recebendo baixos salários com extensas jornadas de trabalho. A queda dos padrões morais da época, que sustentava essa prática dita de enfermagem afastou as mulheres de classe social elevada, iniciando-se assim, o período de decadência da prestação dos cuidados de saúde ${ }^{(9)}$.

Havia outra questão: o papel das mulheres na sociedade estava em processo de mudança, quando estas deveriam resignar-se aos limites de seus lares e obedecer a seus maridos. Assim, o cuidado aos doentes foi deixado a cargo de um grupo de mulheres, a exemplo de prisioneiras e prostitutas, que eram forçadas a trabalhar como serventes domésticas ${ }^{(7)}$.

Junto às inovações culturais e intelectuais da Medicina, ocorre o espírito renascentista, afetando, por conseguinte, a prática de cuidados, que permanece doméstica, manual e desprovida de cientificidade. Por ser exercida por mulheres, o cunho científico era dispensado(10).

A descontinuidade do cuidar se diferencia do curar, pois há no contexto dois saberes: o curar hegemônico, masculino, um saber que se firma política e socialmente na figura do médico e, o cuidar dominado, feminino, doméstico, caracterizado pela figura da enfermeira(11).

\section{Pós-Florence: profissão de Enfermagem e a Teoria Am- bientalista}

Em maio de 1820 nasce Florence Nightingale, durante uma viagem que seus pais, um casal aristocrata da Inglaterra, realizavam pela Europa. Florence cresceu em meio a uma sociedade aristocrática, recebendo uma educação esmerada. Teve sua projeção maior a partir de sua participação como voluntária na Guerra da Criméia em 1854. Florence revolucionou o conceito de enfermeira da época, vindo a conformar o que hoje denominamos de Enfermagem Moderna.
Florence, a então conhecida "dama da lâmpada" por durante a noite velar os soldados feridos da guerra, propagou suas crenças, pensamentos e preceitos que instituíram um modelo de enfermeira, que passou a ser seguido na época, refletindo na atual identidade da profissão, sendo o alicerce sobre o qual se pratica a Enfermagem atualmente.

Florence acreditava que fornecer um ambiente adequado era o diferencial na recuperação dos doentes: nasce a Teoria Ambientalista, desenvolvida na segunda metade do século XIX, na Inglaterra. O meio ambiente era interpretado como todas as condições e influências externas que afetam a vida e o desenvolvimento de um organismo, capazes de prevenir, suprimir ou contribuir para a doença e a morte (12) $^{(2)}$

A teoria ambientalista tem como foco principal a implementação de uma assistência humanizada, fundamentada no controle do ambiente ao redor do paciente, sendo este um ser de relações e interações. Para tal, aborda ventilação, limpeza, iluminação, calor, ruídos, odores e alimentação(13)

Nos dias atuais, a temática saúde ambiental vem sendo discutida tanto nas disciplinas da saúde como nas disciplinas de foco ambiental. As questões ambientais constituem elementos fundamentais para a saúde individual e coletiva. A disseminação de doenças está entrelaçada às relações entre o meio ambiente e a pessoa que adoece ou permanece saudável. A teoria Ambientalista, por analogia, atravessa séculos e se faz cada vez mais atual. Ao refletir sobre as ideias de Florence e o ambiente, chega-se a pensar que nelas se insere o pressuposto de que a saúde do ser humano e o ambiente saudável são elementos essenciais da vida(14).

Curiosamente, o ano do bicentenário de Florence Nightingale, autora da Teoria Ambientalista cursa com uma avassaladora pandemia diretamente relacionada a questões ambientais, como quarentenas, informações e atitudes relacionadas à higiene e ao comportamento social. A Enfermagem, assim como outras profissões da saúde, é homenageada pela mídia e pela população.

Florence, anteriormente citada neste texto como uma das precursoras da ciência se faz presente na atualidade, pois comportamento social, higiene, ventilação, alimentação e outros itens relacionados à saúde e ao ambiente emergem na mídia e no dia a dia das pessoas, que necessitam reaprender que lavar as mãos é premissa para não adoecer

O mundo vive a pandemia pela COVID-19. A ausência de imunidade prévia na população humana, bem como de vacina contra este vírus, faz com que o crescimento do número de casos seja exponencial. Nesse contexto, são indicadas intervenções não farmacológicas, visando inibir a transmissão entre humanos, desacelerar o espalhamen- 
to da doença, e consequentemente diminuir e postergar o pico de ocorrência na curva epidêmica(15). Eis uma das faces da Teoria Ambientalista, preconizando a redução da transmissibilidade, onde o isolamento social se faz necessário. A Teoria Ambientalista é repensada nas entrelinhas de rotinas, regras e propostas de enfrentamento de um agravo que sequer era discutido à época.

\section{Limitações do Estudo}

Como limitações do estudo, consideramos que o limite de 15 citações foi insuficiente para este artigo.

\section{Contribuições do Estudo para a Prática}

Este estudo contribuirá com reflexões acerca da história da Enfermagem, desde os primórdios até a contemporaneidade, onde os fatos não se repetem, mas a história se reafirma. Conhecer a história da Enfermagem faz parte do processo de reconhecimento da profissão como ciência e arte, tal qual descreveu Florence Nightingale.

\section{CONSIDERAÇÕES FINAIS}

A construção de uma identidade profissional, para a Enfermagem Moderna é paralela à (des)construção de estigmas. Porém, a historicidade deve ser desvelada, mas nunca negada.

Ainda há muito que se alcançar. Lembra-se que, comparada a história da humanidade, a Enfermagem e sua historicidade ainda são relativamente recentes. Discorrer sobre tal e toda sua trajetória profissional a partir de marcos clássicos é necessário para o reconhecimento da profissão como um dos pilares da relação entre saúde e ambiente.

\section{CONTRIBUIÇÃO DOS AUTORES}

Eliana Wiggers: concepção e desenho do manuscrito, análise e interpretação dos dados, redação do artigo, revisão crítica, revisão final. Miguir Terezinha Vieccelli Donoso: concepção e desenho do manuscrito, análise e interpretação dos dados, redação do artigo, revisão crítica, revisão final.

\section{REFERÊNCIAS}

1. Silva O, Apolinário M, Oguisso T. A enfermagem em obras clássicas da literatura: estudo com base sociolinguistica. Enferm. Foco [Internet]. 2017. [cited 2020 May 15];8(2):57-61. Available from: http://revista.cofen. gov.br/index.php/enfermagem/article/view/987/382.

2. Santos MG, Bitencourt JVOV, Silva TG. Frizon G, Quinto AS, Marisa Gomes dos Santos. Etapas do processo de enfermagem: uma revisão narrativa. Enferm. Foco [Internet]. 2017 [cited 2020 May 15];8(4):49-53. Available from: http://revista.cofen.gov.br/index. php/enfermagem/article/view/1032/416.

3. Almeida MCP. O saber de enfermagem e sua dimensão prática. $2^{a}$ ed. São Paulo: Cortez; 1989.

4. Campos ES. Breve noticia histórica sobre os hospitais em geral. In Campos ES. História e evolução dos hospitais. 2. ed. Rio de Janeiro: Departamento Nacional de Saúde-Divisão de Organização Hospitalar/Ministério da Saúde; 1965. p. 7-46.

5. Padilha MICS, Mancia JR. Florence Nightingale e as irmãs de caridade: revisitando a história. Rev. bras. enferm. [Internet]. 2005 Dec [cited 2020 May 14]; 58(6):723-6. Available from: http://www.scielo.br/ scielo.php?script=sci_arttext\&pid=S0034-71672005000600018\&lng=en. https://doi.org/10.1590/S0034-71672005000600018.

6. Castro JCM. Vida de Luiza de Marillac: fundadora das irmãs de caridade. Petrópolis: Vozes; 1936.

7. Ellis JR. Enfermagem contemporânea: desafios, questões e tendências. 5aㅗ ed. Porto Alegre: Artmed; 1998.

8. Silva GB. Enfermagem profissional: análise crítica. São Paulo: Cortez; 1986.

9. Geovanini T, Dorneles S, Moreira A, Machado WCA. História da enfermagem: Versões e Interpretações. Rio de Janeiro: Revinter; 1995.

10. Donahue MP. Historia de la Enfermeria. Barcelona: Pilar Vilagrasa; 1985.

11. Rossi MJS. O curar e o cuidar: a história de uma relação (um ensaio). Rev. bras. enferm. [Internet]. 1991 Mar [cited 2020 May 14]; 44(1):16-21. Available from: http://www.scielo.br/scielo.php?script=sci_arttext\&pid=S0034-71671991000100004\&lng=en. https://doi.org/10.1590/ s0034-71671991000100004.

12. Medeiros ABA, Enders BC, Lira ALBC. Teoria Ambientalista de Florence Nightingale: Uma Análise Crítica. Esc. Anna Nery [Internet]. 2015 Jul-Set [cited 2020 Abr 18]; 19(3): 518-524. Available from: http://www. scielo.br/pdf/ean/v19n3/1414-8145-ean-19-03-0518.

13. Moreschi C, Siqueira DF, Dalcin CB, Grasel JT, Backes DS. Homenagem a Florence Nightingale e compromisso com a sustentabilidade ambiental. Revista Baiana de Enfermagem [Internet]. 2011 Mai-Ago, [cited 2020 Abr 18]; 25(2): 203-208. Available from: https://portalseer.ufba.br/ index.php/enfermagem/article/view/5260/4477.

14. Bezerra CMB, Silva BCO, Silva RAR, Martino MMF, Monteira AI, Enders BC. Análise descritiva da teoria ambientalista de enfermagem. Enferm. Foco [Internet]. 2018 [cited 2020 Mai 15]; 9(2):79-83. Available from:

http://revista.cofen.gov.br/index.php/enfermagem/article/ view/1105/450

15. Garcia LP, Duarte E. Intervenções não farmacológicas para o enfrentamento à epidemia da COVID-19 no Brasil. Epidemiol. Serv. Saúde [Internet]. 2020 Abr [citado 2020 Abr 20]; 29(2): e2020222. Available from: https://doi.org/10.5123/s1679-49742020000200009. 